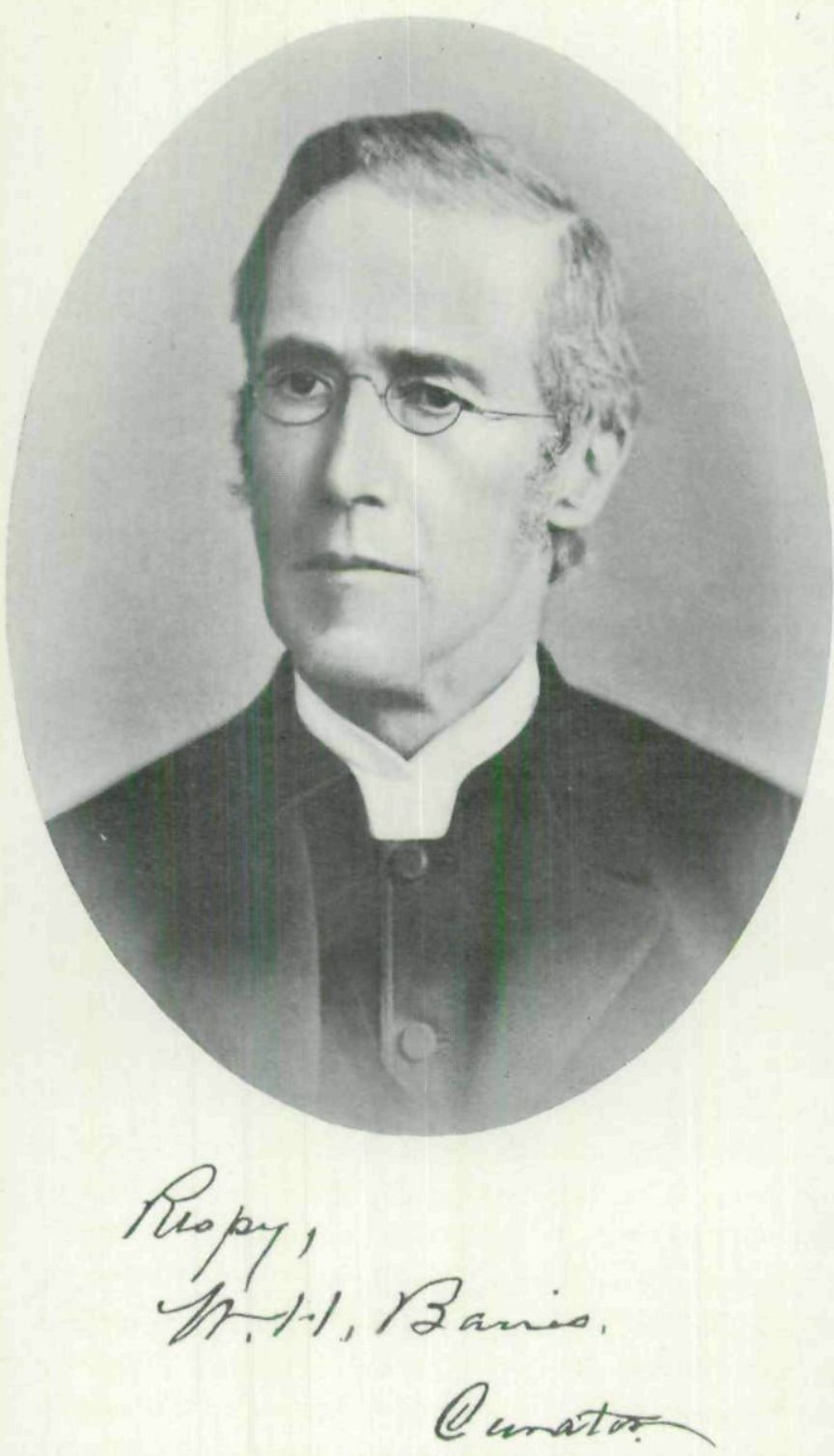

REV. WILLIS HERVEY BARRIS, D, D.

Protestant Episcopal clergyman, geologist, and educator-one of the founders and curator of the Davenport (lowa) Academy of Sciences. 


\title{
REV. WILLIS HERVEY BARRIS, D. D.
}

\author{
BY DR. CHARLES A, WHITE.
}

Professor Willis Hervey Barris, D. D., died at his home in Davenport, Iowa, on June 10th, 1901, full of years and honors and of the loving esteem of all who knew him. His was a life of such usefulness to mankind, such devotion to high principles, and of such value to the State of Iowa, of which he was a citizen forty-six years, that it is fitting THE ANNALS should contain a record of at least its principal events and activities.

Dr. Barris was born in Beaver county, Penn., on July 9th, 1821, spent the years of his early boyhood at his father's home and, in 1835 , at the age of fourteen years, entered Allegheny college at Meadville, Penn. Upon graduating with the degree of A. B. in 1839, he entered upon a post-graduate course of civil engineering in the same college, which course he completed in 1841. In 1854 Allegheny college also conferred upon him the degree of A. M. At the time of his graduation the study of geology and that of biological sciences were not included in the curriculum of any American college; but as a boy he became deeply interested in those studies and as he grew up to manhood that interest developed into mastery of several branches, of which geology and paleontology were his favorites, and in which he prosecuted original studies with marked success.

Upon completing his secular college studies, at the age of twenty-one years, he entered regularly upon his theological course and related studies, and was graduated, in 1850, from the General Theological Seminary at New York city, the oldest theological institution of the Protestant Episcopal church in the United States. He was ordained priest by Bishop De Lancey of New York on September 19th, 1852.

It was with such an educational equipment, and endowed by nature with a most congenial and catholic spirit, that he entered upon his chosen life work in 1851, when he became 
assistant to the rector of St. Luke's church at Rochester, N. Y., the Rev. Henry Lee, who afterward became bishop of Iowa. In the next year he became rector of St. Luke's church at Brockport, N. Y. While engaged in the work of this village parish he yielded to the solicitation of Bishop Lee and also removed to Iowa, becoming rector of Trinity church at Iowa City in 1855. After four years' labor at Iowa City, in 1859, he became rector of Christ church at Burlington, Iowa, where he lived and labored until 1866. He was then called to the Ely professorship of ecclesiastical history (including Greek and Hebrew) in the theological department of Griswold college at Davenport; that chair having been created and endowed with special reference to securing the services of Dr. Barris as its occupant. He accepted that important position and performed its duties with abundant success for twenty-five years.

Although Dr. Barris was eminent as a scholar, a scientist and a citizen, he was above all a churchman; and no doubt his great services to the church at whose altars he ministered so faithfully, whose youth and candidates for its ministry he instructed so thoroughly, and in the management of whose organic and charitable affairs he took so active a part and performed such a multitude of laborious services, will be duly recorded in its special publications. In this sketch, therefore, I will refer to him mainly as a citizen, a scientist, and a personal friend.

At every place to which he was called to labor for the church he immediately applied himself in a hardly less energetic manner to two secular subjects. One was a thorough investigation of the geology of his district, and the other a personal identification of himself with the intellectual interests of the community in which he lived, both within and without the pale of his church. His geological investigations were accomplished by numerous, and often long, excursions on foot, and occasional journeys by conveyance; and the closeness of his observations made all their results of 
scientific value. By means of his discreet association with his fellow citizens he became fully acquainted with the educational status and needs of the whole community, from the lowest to the highest grades of instruction, and was always ready to give his aid and counsel toward their improvement. Wherever, within his reach, there were scientific associations or personal material for their formation, he at once became a leading spirit in their organization and spared no pains or labor to make them successful.

These important secular labors of Dr. Barris began in Iowa while he lived at Iowa City. There he studied the Devonian formation of the Iowa river valley, and it was there he became a member of the board of trustees (which afterward became the board of regents) of the Iowa State University, in 1858. Upon his removal to Burlington he found himself in the midst of a geological locality that, because of the richness of its rocks in certain fossils, especially the Crinoids, has become well known wherever geology is studied. $\mathrm{He}$ at once began the investigation of these rocks and their fossils, made large collections of the latter and, during his whole residence at Burlington, he contributed largely to the creation of that scientific interest with which the Burlington limestone is now regarded by all geologists. Portions of his collections of the Burlington fossils went to the British museum, and his correspondence shows that the authorities of that great institution made flattering acknowledgment of their value. But the most important portion went to the Museum of Comparative Zoology at Cambridge, Mass., and a letter from its founder, Prof. Louis Agassiz, speaks in the highest terms of the scientific value of the work that Dr. Barris was then doing in Burlington. Furthermore, a large number of the new forms that have been described and published in works by various authors, notably in the great work of Wachsmuth and Springer on the Crinoids, were first discovered by Dr. Barris in the Burlington limestone and other Iowa formations. 
Much as he loved Burlington and its rocks and hills, he could not withstand the inducement held out by Griswold college to enter upon educational work there; for the church had no better field of labor to offer any man, and he was known to be peculiarly fitted for the work. But in giving up his rectorship at Burlington and accepting the professorship at Davenport he merely changed the form of his work for the church and gave up only a part of his paleontological studies. Davenport also gave him a broader field for scientific usefulness than he had before enjoyed, and he entered upon his work there with singular devotion. As soon as his college work was well established at Griswold he began to make a careful study of the geology of the region round about Davenport, and from time to time he published valuable articles as results of those and previous studies, mainly in the reports of the Geological Survey of Illinois and the proceedings of the Davenport Academy of Sciences. He was largely instrumental in founding the Davenport Academy and one of its original members. He was made a member of its board of trustees at its first meeting and was elected its president in 1876. He held other important offices in the academy, among which were those of curator and corresponding secretary, the laborious duties of which he performed many years. Indeed, he became so long and thoroughly identified with the executive work of that important institution that the citizens of Davenport, and even the members of the Academy, were accustomed to think of it in connection with his personality.

His establishment in educational work at Davenport together with his previous and continued scientific work, made his name so well known, not only within, but far beyond, the limits of his State that he was made an honorary member of various scientific societies, and in 1869 Griswold college conferred upon him the degree of Doctor of Divinity. Many efforts were also made to secure his services in other institutions, both ecclesiastical and secular, some of which were so 
important that they would have appealed strongly to the ambition of the ablest men. Although these "Macedonian cries" were responsively appreciated by Dr. Barris he saw the line of his duty too clearly drawn at Davenport to justify him in severing his connection with it there. He therefore wisely remained and finished his life work there, where his opportunities were ample and his surroundings congenial.

It would be impossible, except in an exhaustive memoir, to discuss the various ways in which Dr. Barris made himself conspicuously useful as a citizen, or to trace the beneficent influence of his life and teachings upon the people, both old and young, with whom he came in contact. Much of his work and influence must doubtless go unrecorded, but it will be only with death that those who knew him personally will cease to derive practical benefit from them.

Dr. Barris was twice married. His first wife was Miss Caroline M. Harrison of Meadville, Penn., to whom he was united October 7, 1840. She died in 1850, leaving him with two young daughters, one of whom, Mary Elizabeth, survives and is now the wife of Archdeacon S. R. J. Hoyt, D. D., of Davenport. His second wife was Miss Caroline P. Rathbone of Le Roy, N. Y., to whom he was united on May 9, 1854. She was his faithful and helpful companion through all the years of his most successful and abundant labors, and now survives him. Their three surviving children are Carrie Rathbone, the wife of Mr. Edward S. Hammatt of Davenport, and the Misses Amanda Ganson and Bessie Lovering Barris.

The accompanying portrait represents, to a good degree, his personal appearance, and suggests something of his personality to those who knew him. Those who were thus favored, however, will not need this memento to remind them of his genial manner, his frank and kindly speech, and his quickly responsive interest in everything that is good; and he was disposed to see "good in everything." His tact and affability with both the wise and the ignorant were such that no one was ever embarrassed in his company, and his 
sincerity and quiet dignity were such that no one ever thought of taking a liberty in his presence. My acquaintance with him began by means "of the identity of the subjects of our scientific investigations, and we often met for an interchange of views. It was my good fortune to secure his confidence, and my privilege to call him my friend during more than forty years; and I never had an interview with him, or received a letter from him, that did not add to the sum of my life's enjoyments, to my stock of knowledge, and to my confidence in humanity. He was an ideal friend, an eminently useful citizen, a profound scholar, a most efficient teacher, and a devoted Christian minister. The memory of such a man is a blessing to the State.

Smithsonian Institution, September 6, 1901.

Mr. Abraham Slimmer of Waverly does not weary in well doing. His latest philanthropic proposal is for a free hospital for Bremer county. He proposes to give his home to the Sisters of Mercy, the same to be used exclusively for hospital purposes, and admission to be free to people of all races and religions. Here is a happy state of affairs; a Jew offers to give his money over to the care of a Catholie order who are to minister to the welfare of a community altogether Protestant.-Des Moines Leader, Sept. 7, 1901.

Death of James G. Edwards.-We are pained to hear of the death of that veteran editor and kind-hearted man, James G. Edwards, late of The Burlington Hawk-Eye. Mr. $\mathrm{E}$. has been connected with the press of Iowa for thirteen years. In 1838 he established The Hawk-Eye in Burlington, where he continued its publication until a few weeks before his death. He was an upright, warm-hearted man; a bold and vigorous writer, and an estimable citizen.

-Keosauqua Ameriean, Aug. 9, 1851. 
Copyright of Annals of Iowa is the property of State of Iowa, by \& through the State Historical Society of Iowa and its content may not be copied or emailed to multiple sites or posted to a listserv without the copyright holder's express written permission. However, users may print, download, or email articles for individual use. 